\title{
Investment in Financial Structured Products from a Rational Choice Perspective
}

\author{
Moran Ofir* \\ Zvi Wiener**
}

\begin{abstract}
Structured products (SP) are synthetic investment instruments tailored to the specific needs of an investor, which cannot be met through investment in standard financial instruments. Despite the large sums invested in SP, regulation, which adequately addresses issues arising from the investment in these packaged financial instruments is lacking. Many of these issues are unique to SP and do not pertain to investments in 'plain vanilla' stocks, bonds and mutual funds. We argue that many structured products currently available to retail investors are designed to exploit several common behavioral biases in the area of decision making under uncertainty, including: loss aversion, the disposition effects, herd behavior, the ostrich effect and the hindsight bias. We identify certain characteristics of structured products and analyze the association between these features and the corresponding behavioral bias. To test our argument, we perform an experiment that examines investor decision-making in relation to SP investments. Our findings demonstrate that investors tend to be affected by these behavioral biases, which favor SP investments, despite the fact that a rational assessment of investor welfare would lead to an alternative investment. Accordingly, regulation dealing specifically with SPs may be warranted to improve investor protection.
\end{abstract}

\footnotetext{
*School of Business Administration and the Center for Rationality, The Hebrew University of Jerusalem.

** School of Business Administration, The Hebrew University of Jerusalem.

We would like to thank Uriel Procaccia for his superb guidance, support and contribution. We are grateful to Sari Carp, Dan Galai, Gitit Gur-Gershgoren, Roni Michaely, Orly Sade and Ro'i Zultan, and the participants of the Center for Rationality annual retreat, the Hebrew University of Jerusalem, and the participants of the Asia-Pacific Economic Science Association 2009 meeting, and the participants of the Capital Market Colloquium, The Israeli Securities Authority (ISA) for their helpful comments. We thank June Dilevsky for editorial assistance.
} 


\section{Introduction}

Structured products are pre-packaged financial instruments comprising securities and derivatives bundled into a single derivative instrument. One of the key characteristics of structured products is that the return is determined by a pre-specified formula, which sets out the product's performance in any possible future scenario. Unlike mutual and other types of investment funds, the outcome of an SP is not a function of on-going active investment.

The structured products market has existed for over ten years but has grown significantly over the last few years. Large retail markets for structured products exist in all major European countries as well as in North America, Asia, Australia and New Zealand. Structured products have also been introduced in many emerging markets such as Eastern Europe and South Africa. ${ }^{1}$

Structures typically use derivatives to create tailored returns. These derivatives can be plain vanilla or exotic and can be linked to various indices, commodities or foreign currency exchange rates. Investors in structured products range from retail investors to high-net worth individuals, institutional investors, and corporations.

Derivatives constitute an essential ingredient of any structured product, since they enable the customization of return profiles. Accordingly, investment banks active in derivative markets have traditionally driven new product development and have provided retail product vendors the ability to hedge exposure when new products are launched. These include retail banks, building societies, and fund managers, which market financial products either directly to existing customers or via third-party distributors such as financial advisers.

Structured products have no exact definition, neither in a business context nor in a regulatory context. U.S., regulators such as the $\mathrm{SEC}^{2}$ and FINRA $^{3}$ employ a broad

\footnotetext{
${ }^{1}$ Source: Structured Retail Products.com.

${ }^{2}$ SEC Rule 434.
} 
definition. Under this definition, a structured security is a security derived from or based on another security, basket of securities, index, commodity, or foreign currency. This definition covers a wide range of products, including equity-linked or commodity-linked debt, collateralized debt obligations (CDO), reverse convertibles, and credit-default swaps (CDS). The European Union's Markets in Financial Instruments Directive (MiFID) defines the concept of 'complex' vs. 'non-complex' financial instruments'. A noncomplex product is a liquid investment, which does not comprise any actual or potential liability which exceeds the cost of the instrument and for which adequate information about is publicly available ${ }^{4}$. Any securities not meeting these criteria are considered 'complex' instruments. While this categorically includes all types of non-negotiable securities it also includes derivatives as well as debt instruments with embedded derivatives. European legislation does not offer an exact definition to structured product.

Interest in structured products as a method of portfolio diversification and as a sole investment has grown in recent years. The growth in new structured product issues in the U.S. market between the years 2003-2007 is demonstrated in Figure 1:

Figure 1: U.S. Structured Products: New Issues, 2003-2007 (USD billions)

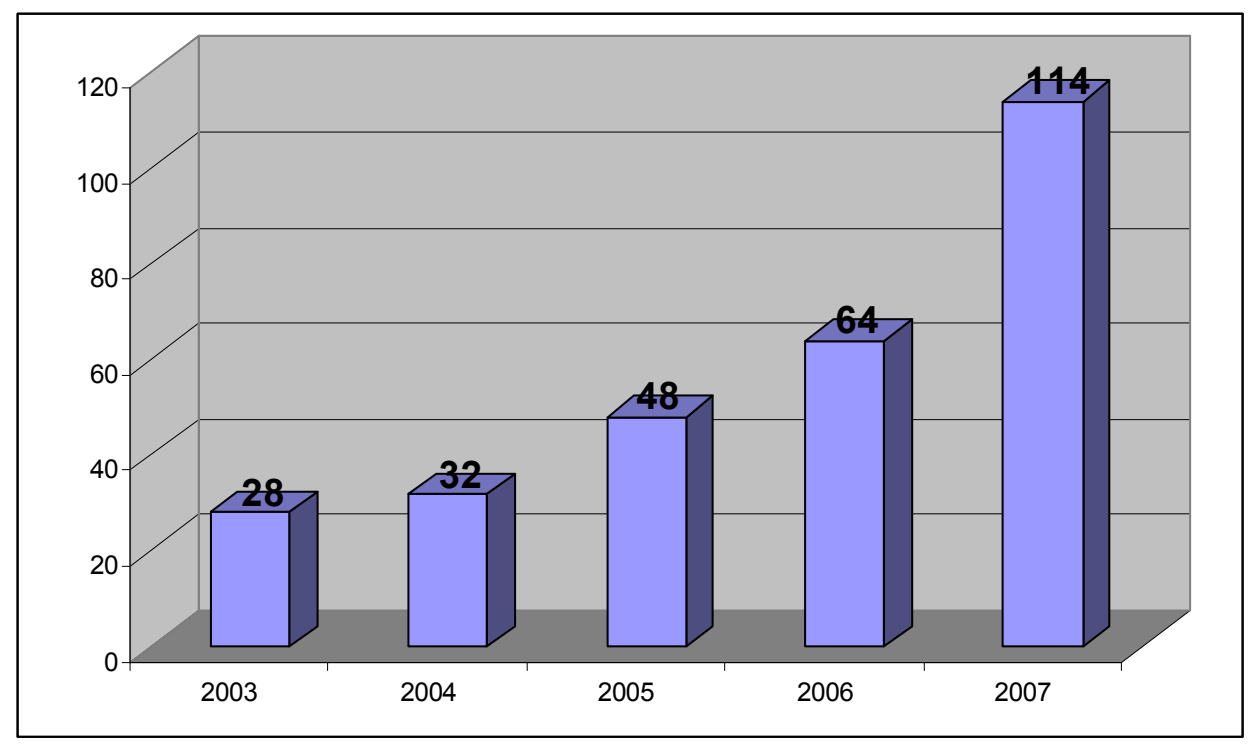

Source: Structured Products Association

${ }^{3}$ FINRA Regulatory Notice 08-81; NASD Notice to Members 05-59.

${ }^{4}$ MiFID, Article 39. 
Relative to the European market, the U.S. market lags behind in the penetration of structured products in retail markets. As Figure 2 demonstrates, the size of the U.S. retail market is approximately half that of the European market.

Exhibit 2: Gross Sales of Structured Products to Retail Investors in 2005 (USD billions)

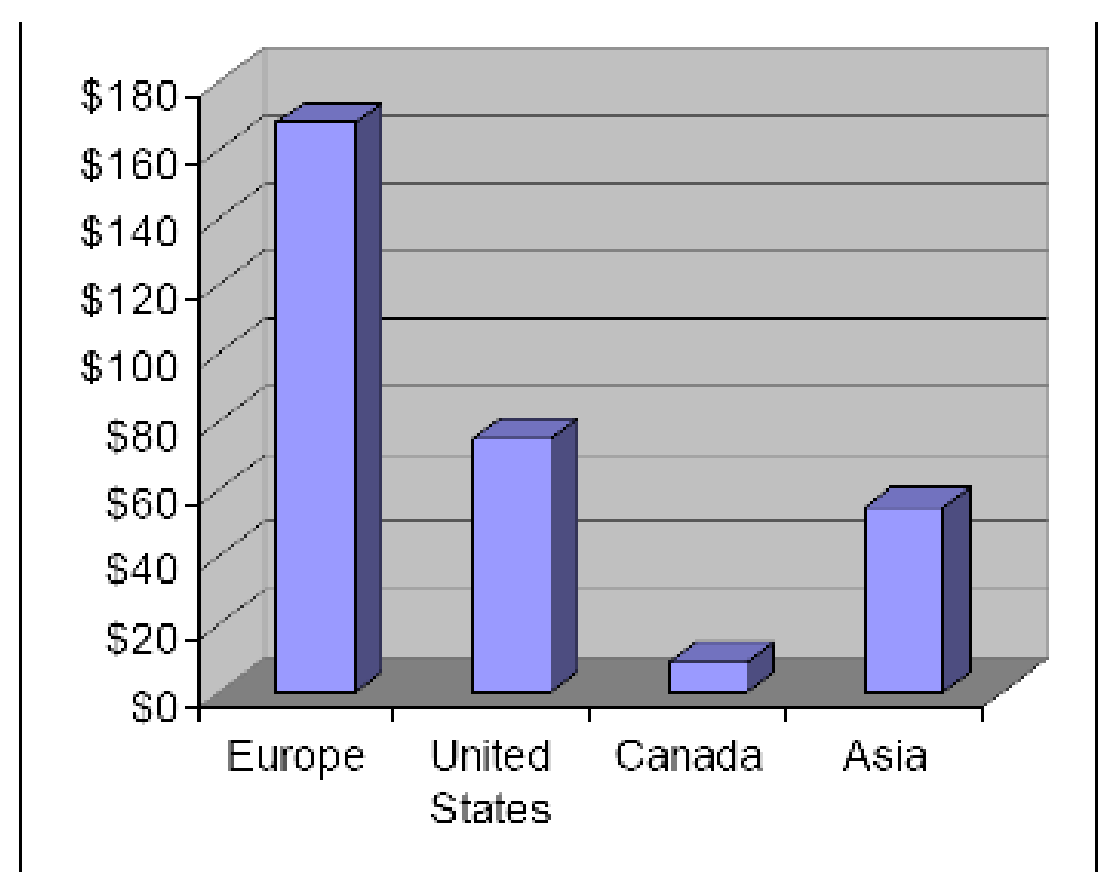

Soures: brtp:/www-stuenuedretailproducts.con.

Recent evidence suggests a growing propensity for retail investors in the United States to purchase structured products listed on public exchanges. The American Stock Exchange reported an 18 percent increase in the number of listed structured products issues in 2005 over 2004, bringing the notional amount of structured products on the AMEX to over $\$ 13$ billion. ${ }^{5}$ The New York Stock Exchange reported $\$ 14$ billion in new listings in corporate-issued structured products in 2005.

Exchange-traded structures constitute only one segment of the structured products market; another important segment is the non-negotiable structures market, distributed primarily by investment and commercial banks. Both the exchange-traded and non-

${ }^{5}$ Structured Products Association Chairman's Letter, February 2006, p2. 
negotiable segments of the structured products market experienced growth throughout the bull market period between 2003 and 2007.

Structured products enable financial institutions to better serve their customers by offering them a broader menu of financial instruments and greater flexibility in tailoring portfolios to individual needs and outlooks. The primary objective for issuers marketing structured products is to increase profit margins. The packaging of securities often enables issuers to obscure commissions and fees. In addition, these financial instruments are normally crafted to generate demand for bank services by signaling that the issuing bank is a reliable and highly sophisticated financial firm. .

The benefits structured products offer investors can include: principal protection on equity market-linked investments; opportunities to realize enhanced returns within an investment; additional alternatives for risk management; tax-efficient access to fully taxable investments; and accounting advantages. While investors may be able to replicate investment strategies on their own, the purchase of structures obviates the need for active management of complex investment strategies. Structured products can be used as an alternative to direct investments in financial assets, as a means to mitigate the risk exposure of a portfolio, or as a way of exploiting market trends. Structured products allow market participants who opt for a specific schedule of payments over time to access this schedule, while hedging certain risks. Structured products also enable investors to more fully to diversify their investment portfolios, since they can access asset classes that may not be available to them otherwise.

Structured products have no specific regulation, in spite of the large volume of funds investment in them. Indeed, unlike traditional financial instruments such as stocks, bonds, and mutual funds, structured products raise important concerns about investor protection. Regulators around the world have considered reforms in securities regulation for structured products in recent years. 
While structures contribute to the completeness of modern financial markets by enhancing alternatives open to investors, they have a definite downside. We argue that most structured products available on the market are designed to exploit a number of common behavioral biases observed in the area of decision-making under uncertainty. It is highly likely that unsophisticated investors ("noise" traders) often fall prey to manipulative marketing techniques and ultimately make sub-optimal investment decisions. Therefore, we believe that specific regulation for structured products may be warranted in order to protect retail investors.

When investors decide whether to invest in structured products, their decision patterns often fall short of conforming with von Neumann and Morgenstern's axioms. Since investors do not satisfy these axioms, they do not behave as if they assign utilities to consequences and alternatives and then pursue the alternatives consistent their greater subjective expected utility. As a result, wealth is transferred from the investor to the issuer of structured products.

The first part of our paper demonstrates the transfer of wealth from the investor to the issuer for a typical structured product. We identify several features of structured products, and show how these are associated with specific behavioral biases. Our insights are derived from theories associated with various aspects of decision theory: loss aversion, the disposition effect, herd behavior, the ostrich effect and hindsight bias. Appendix 1 summarizes selected structure features and the corresponding behavioral biases. To examine investor decision-making in relation to the investment in structured products, we conduct an experiment. The experiment tests each bias individually to determine whether investors are influenced by a given bias to such an extent that they favor investment in a structured product over a more beneficial alternative. 


\section{An economic analysis of typical structured product}

The following example illustrates the riskless transfer of wealth from the investor to the issuer for a typical structured product. This structured deposit provides investors equity exposure with limited principal protection. Alternatively, an investment in this structure can be viewed as a convertible corporate bond, with a compulsory conversion clause for the investor. Its description was translated from the website of one of Israel's leading commercial banks as follows:

"This structured deposit yields a 9.54\% interest rate, payable unconditionally after one year. The principal will either be paid in full or converted to "Teva" shares traded on NASDAQ, if the share price declines as follows:

At maturity the investor will receive a high, unconditional, 9.54\% annual interest rate.

The principal will be paid in full if at least one of the following does not occur:

1. The share price of Teva Pharamceuticals decreases at least once during the deposit period by $25 \%$ or more, relative to the share price set on the day the deposit is opened.

2. The closing share price of Teva Pharmaceuticals on the deposit's maturity date is lower than its price upon the initial opening of the deposit.

Should both of the above-mentioned conditions be fulfilled, the principal will be converted into Teva shares according to the deposit's opening-day share price, and the investor will receive the shares and the $9.54 \%$ interest on the principal"

This structured product consists of the following underlying assets:

The issuer sells (writes) a one-year knock-in put option triggered at a share price $25 \%$ lower than the price on the day the option is issued. 
The premium to this option, according to Bloomberg's stock option calculator is $11.51 \%$.

The premium and the principal are invested in twelve-month T-Bills (annual return on the date of issue was $5.16 \%$ ).

Assuming an investment of US\$100,000:

Premium $=11.51 \%$ x US $\$ 100,000=U S \$ 11,510$

Future Value of T-Bills=US $\$ 111,510 \times 1.0516=\mathrm{US} \$ 117,264$

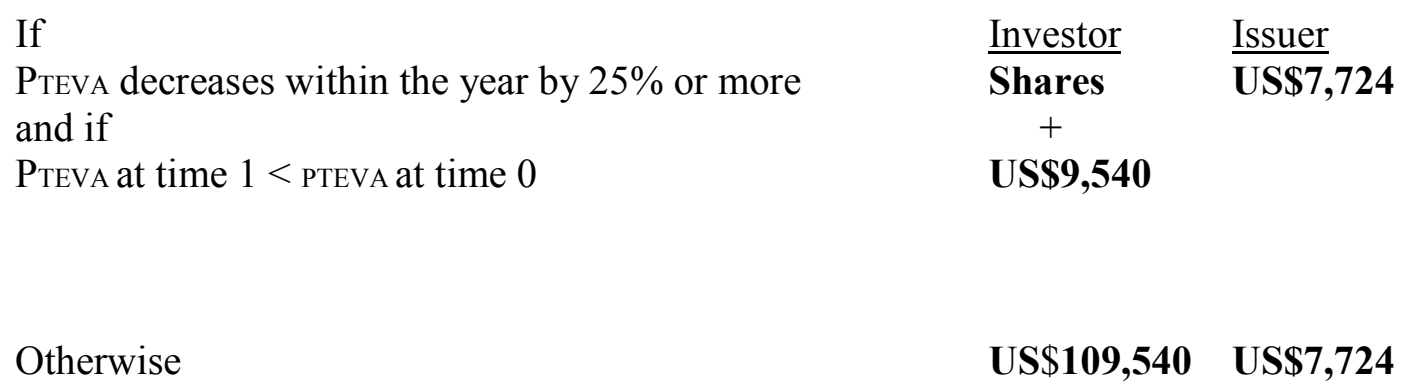

Pteva decreases within the year by $25 \%$ or more and if

Pteva at time $1<$ PTEVA at time 0

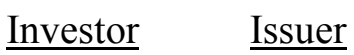

Shares $\quad$ US\$7,724

$+$

US\$9,540

Otherwise

US\$109,540 US\$7,724

The issuer receives the same amount, regardless of the stock price at maturity which represents a $7.7 \%$ effective fee on the funds invested in the structured product. The investor receives $9.54 \%$ and depending on share price movements, either the principal or, the shares. The latter alternative is triggered upon a substantial decline in share price and incorporates the losses accrued during the deposit period.

\footnotetext{
${ }^{6}$ This option is not traded; therefore the estimated premium can also compute as $0.9 * 11.51 \%=10.36 \%$. In this case, the issuer receives US\$ 6,514 on every US\$ 100,000 invested in the structured product, regardless of the share price at maturity.
} 


\section{A behavioral analysis of structured products}

This paper focuses on five features commonly found in structured products, and the behavioral biases associated with them. In this section we outline these behavioral biases and analyze the relation between each bias and the corresponding feature.

\section{A. Loss Aversion}

Loss aversion refers to the tendency for people strongly to prefer avoiding losses than acquiring gains. A key conclusion of Kahneman and Tversky's 1979 study of decisionmaking under uncertainty is that choices are best explained by assuming that the significant carriers of utility are not states of wealth, but rather changes relative to a neutral reference point, such as the status quo. They also found that losses loom larger than gains. Empirical estimates of loss aversion demonstrate that the perceived disutility of loss is twice as great as the utility of gain (Tversky and Kahneman, 1991).

Myopic loss aversion, as articulated by Benartzi and Thaler (1995), describes the process of mental accounting ${ }^{7}$ regarding the flow of information, in which individuals tend to be more sensitive to reductions in the level of well-being than to increases. Myopic loss aversion predicts that dynamic aggregation rules influence investor attitudes toward risk. The frequency with which the information is presented can have an impact on the willingness of an investor to undertake risky investments. Frequent reporting leads to a preference for less risky portfolios.

Structured products are considered by investors as less risky investments, primarily because most promise principal protection. Principal protection enables lossaverting investors to avoid losses and enjoy gains in certain circumstances. Investors, especially retail investors, consider principal protection a very attractive feature, and their decision whether to invest in a structured product is strongly affected by it.

\footnotetext{
${ }^{7}$ Mental accounting, as presented in Benartzi and Thaler (1995), refers to the implicit methods individuals use to code and evaluate financial outcomes.
} 
It is well worth noting in this context that principal protection is usually nominal and not real, and it does not carry any compensation for the time value of money. Moreover, in some structured products the principal protection is in foreign currency which exposes the principal to foreign currency exchange rate risks. In short, principal protection is not necessarily what one would wish it to be, nor perhaps what retail investors assume it to be.

\section{B. The Disposition Effect}

Identified by Kahneman and Tversky (1979), the disposition effect refers to an aversion to loss realization. Shefrin and Statman (1985) examine this feature within the context of financial markets. Specifically, they examine decisions to realize gains and losses in a market setting. They develop a descriptive theory of capital gain and loss realization in which investors tend to "sell winners too early and ride losers too long," relative to the prescriptions of the normative theory. Using evidence that suggests that this tendency applies in real-life financial markets, Shefrin and Statman demonstrate how the tendency to sell winners and ride losers emerges in prospect theory in the following example:

Consider an investor who purchased a stock one month ago for $\$ 50$ and who finds that the stock is now selling at $\$ 40$. The investor must now decide whether to realize the loss or hold the stock for one more period. To simplify the discussion, assume that there are no taxes or transaction costs. In addition, suppose that one of two equiprobable outcomes will emerge during the coming period: either the stock will increase in price by $\$ 10$ or decrease in price by $\$ 10$. According to prospect theory, our investor frames his choice as a choice between the following two lotteries:

A. Sell the stock now and realize a $\$ 10$ loss.

B. Hold the stock for one more period, given 50-50 odds between losing an additional \$10 or "breaking even."

Since the choice between these lotteries is associated with the convex portion of the S-shaped value function, prospect theory implies that B will be selected over A. That 
is, the investor will ride his losing stock. An analogous argument demonstrates how prospect theory accounts for a propensity towards profit-taking.

In our research, the relevant behavioral phenomenon is the aversion to loss realization, or in other words, the disposition to "ride losers," as presented in the numerical example. Many structured products include mandatory conversion provisions. Conversion is triggered when the price of the underlying asset falls past a predetermined threshold during the investment period. If the price does not cross this threshold, the investor receives the principal plus a relatively high return. The conversion into the "losing" asset typically reflects a higher price (ej. the market price at time of issue) than the market price of the asset at the time of the structured product's maturity.

The mandatory conversion feature is activated by the investor tendencies to "ride losers" because the conversion into "losing" assets puts off the realization of losses. Investors will continue to ride the losing asset in the near future and will not realize the loss caused by the investment in the structured product.

\section{Herd Behavior}

Herd behavior can explain the phenomenon of large numbers of people acting in the same way at the same time. Large stock market trends, bubbles, and crashes often begin and end with periods in which a large number of investors buy or sell stocks. Individual investors join the crowd of others in a rush to enter or exit the market.

The literature on herd behavior is extensive. Leibenstein (1950) defined it as the extent to which demand for an asset is increased due to the fact that others also purchase the asset. He explained the motivations underlying herd behavior as "the desire of people to purchase a commodity in order to get into 'the swim of things'; in order to conform with the people they wish to be associated with; in order to be fashionable or stylish; or, in order to appear to be 'one of the boys."” 
Herd behavior has also been explained in terms of a network effect. The network effect was first defined by Katz and Shapiro (1985) as follows: "There are many products for which the utility that a user derives from consumption of the good increases with the number of other agents consuming the good. ... The utility that a given user derives from the good depends on the number of other users who are in the same 'network' as he or she." The main assumption underlying the network effect is the existence of complete information. It is assumed that individuals possess identical motivations and expectations regarding the benefits of goods.

Bikhchandani, Hirschleifer, and Welch (1992) modeled herd behavior under imperfect information. In their model, herd behavior occurs "when it was optimal for an individual, having observed the actions of those ahead of him, to follow the behavior of the preceding individual without regard to his own information." The decision-maker observes the actions of others and assumes that they hold more valuable information than he/she.

The most common explanation regarding herd behavior in financial markets is this last one. Nonprofessional investors follow the behavior of other investors, assuming that the latter hold more valuable information on the market conditions and trends. In our research we concentrate on the first and the last explanations.

Investment in structured products enables the investor not only to follow valuable information held by others, but also to conform to the people with whom they wish to be associated, without risking one's entire funds in a specific investment. If, on the one hand, investors are motivated solely by the information presumably held by other investors, they would invest directly in the underlying asset. If, on the other hand, investors are motivated by a desire to be fashionable and are uncertain about the value of third-party information, they would invest in structured products, which provide only partial exposure to the underlying asset. We cannot rely entirely on the last explanation, because investment in structured products may be motivated by a combination of factors. 
Structured products, providing investors exposure to commodities, emerging markets and to exotic financial products can exploit herd behavior. For example, structured notes linked to emerging market indices facilitate portfolio diversification in potential growth economies. Investors who purchase these market-linked products can conform to people with whom they wish to be associated without exposing the entire fund to the risk of the specific emerging market.

\section{The Ostrich Effect}

The impact of liquidity on the prices of financial assets occupies center stage in the finance literature. The rational pricing of financial assets supports the assessment of a positive correlation between liquidity and prices; i.e., illiquidity has an adverse impact on asset value. When compared with otherwise identical illiquid assets, liquid assets should have a lower yield-to-maturity, given the opportunity to liquidate the position at any juncture and the possibility to realize even a larger return in the market without risking the locked-in return if held to maturity.

Galai and Sade (2006) found that investors prefer to hold illiquid assets and are even willing to pay a premium for them. They attribute this seemingly anomalous behavior to an aversion to receiving information on potential interim losses. The ostrich effect is defined as avoiding apparently risky financial situations by pretending they do not exist. In other words, certain individuals, when faced with uncertainty, prefer investments for which the risk is unreported to similar investments (as far as risk and return are concerned) for which the risks are reported frequently. Support for ostrich effect behavior can be found in various types of financial markets and countries. ${ }^{8}$

Most structured products are non-negotiable, and hence illiquid. Investors can avoid apparently risky financial situations throughout the lifetime of an illiquid structure by assuming these situations do not exist. The only situation with which the investors are concerned is the one occurring at maturity.

\footnotetext{
${ }^{8}$ As demonstrated in Galai and Sade (2006, Section IV, part C).
} 


\section{E. Hindsight Bias}

Hindsight and foresight differ formally in the information available to the observer. Hindsightful decision-makers possess knowledge regarding past outcomes. Foresightful decision-makers do not possess this knowledge. Initially documented by Fischhoff (1975), the hindsight bias refers to the tendency to alter perceptions of the inevitability of an event once the outcome is known.

Fischhoff found that reporting an outcome's occurrence increases its perceived probability of occurrence, and that decision-makers who have received outcome knowledge are unaware of the change in the perceived probability of occurrence. Therefore, reporting an outcome produces an unjustified increase in its perceived predictability, for it seems to have appeared more likely than it actually was.

When the hindsight bias is operating, events that occurred are retrospectively seen as having been more likely to occur and events that did not occur are retrospectively seen as having been less likely to occur. Investors tend to be unaware of the role outcome knowledge plays on their perceptions. Thus, investors tend to believe that seemingly inevitable outcomes were largely apparent in foresight, and these investors tend to invest in products that rely on realized outcomes.

Most structured products rely on an outcome that occurred in the recent past, and are based on the presumed increase in the probability that the same outcome will reoccur in the near future. These structured products guarantee investors relatively high returns should a recent outcome reoccur at maturity. The hindsight investor assesses higher probability to this and tends to favor investing in the structured product. 


\section{$\underline{\text { Testing Behavioral Biases in Structured Product Investments }}$}

We designed a controlled experiment to test our hypothesis concerning the application of behavioral anomalies to investment decisions involving structured products. The purpose of the experiment is to find the influence of each behavioral bias on the investment decision in structured products. Each behavioral bias is examined separately. The original experiment was drafted in Hebrew; a translation of the experiment to English is provided in Appendix 4).

\section{Method}

The experiment comprises seven investment decisions, each involving a binary choice between two mutually exclusive investment alternatives. The distinction between the two investment alternatives is based on the behavioral bias tested in the specific investment decision.

The experiment also contains three additional ranking questions in order to neutralize the potential impact of other values on the investment decisions.

The general instructions describe a situation in which the subjects are in possession of a certain amount of money that they wish to invest in the best possible investment. The participants were instructed to choose only one out of the two investment alternatives for each investment decision. They were told that each investment decision should be considered separately and that in each investment decision, the same amount of money is available to them.

Our subject population consists of 122 investment advisor candidates, ${ }^{9} 104$ executive MBA students at the Jerusalem School of Business Administration, and 42 employees from various industries (other than the financial services industry) for a total of 268 subjects. The subject population reflects non-professional investor households.

\footnotetext{
${ }^{9}$ The investment advisor candidates participated in the experiment during their licensing exams, administered by the Israel Securities Authority.
} 


\section{A. Loss Aversion}

In order to examine the impact of loss aversion on the investment decision in structured products, the subjects faced two investment decisions. Both investment decisions offer the investor a choice between a risky investment in a one-year deposit that is dependent on the exchange rate between the Swiss Franc and the Israeli Shekel, and a safe investment in a one-year deposit that ensures the investor a certain return independent of the aforementioned exchange rate.

The two investment decisions can be drawn as follows:

\section{$\underline{\text { Investment decision } 1}$}

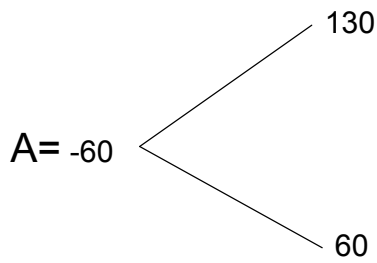

$B=-60 \longrightarrow 90$

\section{Investment decision 2}

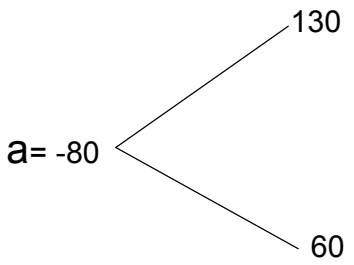

$b=-80 \longrightarrow 90$

One of the risky investments was designed so that with some probability there is a possibility for loss (a). The other risky investment does not face the investors with a possible loss (A). The outcome of the two risky alternatives is equal and the outcome of the two riskless alternatives is equal. We would expect risk averse investors to prefer the riskless investment to the risky one in both investment decisions, or in other words, to reduce the variance of their investment's outcomes in both decisions. We would also expect risk-lover investors to prefer the risky investment to the safe one in both decisions. 
Choosing the risky investment in the first decision and the riskless investment in the second decision can be only explained by loss aversion.

\section{$\underline{\text { Results }}$}

The subjects' choices in the two investment decisions are summarized in Table 1 . The rows reflect the choice between a risky investment with no potential losses (denoted as A) and a safe investment (denoted as B). The columns reflect the choice between a risky investment with potential losses (denoted as a) and a safe investment (denoted as b).

Table 1

\begin{tabular}{|c|c|c|}
\hline & $\mathrm{a}$ & $\mathrm{b}$ \\
\hline $\mathrm{A}$ & $27.61 \%$ & $33.21 \%$ \\
& & \\
\hline $\mathrm{B}$ & $8.21 \%$ & $30.97 \%$ \\
& & \\
\hline
\end{tabular}

The findings show that $33.21 \%$ of the subjects preferred the risky investment to the safe one when there were no potential losses, and preferred the safe investment to the risky one when the potential for loss emerged. The results yielded a significant chi square statistic $\chi^{2}(1)=16.6, p<0.001$. Consequently, loss aversion did influence a substantial part of the subjects in their decision.

\section{B. The Disposition Effect}

In order to examine the impact of the disposition effect on the investment decision in structured products, the subjects faced two investment alternatives. Both alternatives represent two very similarly structured products. The only difference between the alternatives is that in the first, in the worst-case scenario, the initial fund is mandatorily converted into equity, while in the second alternative, in the worst-case scenario the investor is given a cash settlement. The subjects were informed that the implied price of 
the underlying asset upon conversion exceeds the market price of the share at maturity, i.e. losses while not realized, have been accrued.

Should the majority of investors prefer the mandatory conversion structure to the cash alternative, this would constitute evidence of the prevalence of the disposition effect on investment decision-making.

\section{Results}

The subjects' choices are summarized in Table 2. The left column represents the percentage of investors who preferred the mandatory convertible structure product to the nonconvertible one.

Table 2

\begin{tabular}{|c|c|}
\hline Shares & Cash \\
\hline $71.27 \%$ & $28.73 \%$ \\
& \\
\hline
\end{tabular}

As reported in Table 2, 71.27\% of the subjects preferred the mandatory conversion to liquidation. The results yielded a significant chi square statistic $\chi^{2}(1)=48.49, \mathrm{p}<0.001$. Apparently, the disposition effect played a role in decision-making for a majority of the subjects.

\section{Herd Behavior}

To test the impact of herd behavior on investment decision-making for structured products, the subjects faced two investment decisions. Both investment decisions offer the investor a choice between two structured products. In one of the investment alternatives, the return is linked to the performance of a "fashionable" financial asset, and in the other investment alternative, the return is linked to the performance of an "unfashionable" financial asset. 
A financial asset is considered "fashionable" due to its appearance in the mass media. We chose two different "fashionable" financial assets. One of them is a "cleantech" fund that invests in companies that are engaged in technological developments designed to help protect the environment. The other fashionable financial asset is an emerging market index. In each investment decision, the subjects were asked to choose between a "fashionable" structured product and an "unfashionable" one, all the other conditions being equal. The subjects were informed that both underlying assets in every investment decision (the "fashionable" and the "unfashionable") performed equally over the past year.

The experiment also contained three ranking questions in order to ensure that the investment decisions were not affected by other values. The subjects were asked to rank the values appearing in every investment alternative according to importance. We did not find any significant discrepancies between the importance rankings of the different values. Therefore, these values appear not to provide a satisfactory explanation of the investor choice.

Should a majority of investors prefer the "fashionable" over the "unfashionable" structure in each case, this would support the hypothesis that herd behavior comes into play in investor decision-making.

\section{$\underline{\text { Results }}$}

Investment decision preferences are summarized in Tables $3 \mathrm{a}$ and $3 \mathrm{~b}$. Table $3 \mathrm{a}$ represents the choice between a structured product specializing in "cleantech" environmental enterprises and a structured product whose return is linked to the performance of a fund specializing in start-ups, all other conditions being equal. Table $3 \mathrm{~b}$ represents the choice between a structured product tracking an emerging market index and one tracking a developed market index ${ }^{10}$, all other conditions being equal.

\footnotetext{
${ }^{10}$ The experiment was conducted before the 2008 financial crisis, at a time when emerging markets investments were extremely popular.
} 
Table 3a

\begin{tabular}{|c|c|}
\hline $\begin{array}{c}\text { Start-up } \\
\text { Fund }\end{array}$ & $\begin{array}{c}\text { Environmental } \\
\text { Fund }\end{array}$ \\
\hline $27.61 \%$ & $72.39 \%$ \\
\hline
\end{tabular}

Table $3 b$

\begin{tabular}{|c|c|}
\hline $\begin{array}{c}\text { Indian } \\
\text { Index }\end{array}$ & $\begin{array}{c}\text { Italian } \\
\text { Index }\end{array}$ \\
\hline $82.46 \%$ & $17.54 \%$ \\
& \\
\hline
\end{tabular}

As reported in Table 3a, $72.39 \%$ of the subjects preferred the "fashionable" cleantech product to the less fashionable start-up fund. The results yielded a significant chi square statistic $\chi^{2}(1)=53.73, p<0.001$. As reported in Table $3 b, 82.46 \%$ of the subjects preferred the "fashionable" emerging market product to the "less fashionable" developed market alternative. The results yielded a significant chi square statistic $\chi^{2}(1)=112.97$, $\mathrm{p}<0.001$. Consequently, herd behavior apparently did affect the decision of a majority of subjects.

\section{The Ostrich Effect}

To examine the impact of the ostrich effect on structured product investments, the subjects faced two alternatives. Both alternatives are similar structured products. The only difference between the two alternatives is that the first is non-negotiable and the second is a highly liquid product, which can be redeemed by the issuer or traded on a secondary market. All the other conditions are equal.

When compared with an otherwise identical illiquid asset, a liquid asset should have a lower yield to maturity, given the opportunity to liquidate the position on demand and the possibility of realizing larger market returns without jeopardizing the locked-in 
yield-to-maturity. Accordingly, we would expect rational investors to prefer the liquid over non-negotiable structures.

Unlike all the other investment decisions in our experiment, we presented investors with two alternatives to which they should be indifferent; this investment decision includes a superior alternative. Should any significant segment of investors prefer the inferior illiquid to the liquid structure, this would provide evidence supporting the existence of the ostrich effect on investor decision-making.

\section{$\underline{\text { Results }}$}

Investor selections are summarized in Table 5. The left column represents the percentage of investors who preferred the illiquid structure product to the liquid one.

Table 5

\begin{tabular}{|c|c|}
\hline Illiquid Investment & Liquid Investment \\
\hline $35.58 \%$ & $64.42 \%$ \\
& \\
\hline
\end{tabular}

As reported in Table 5,35.58\% of the subjects preferred the non-negotiable over the liquid structure. This finding yielded a significant chi square statistic $\mathrm{p}<0.001$. Consequently, the ostrich effect did have an apparent impact on decision-making for a significant segment of the subjects.

\section{E. Hindsight Bias}

To examine the possible impact of hindsight bias on investments in structured products, the subjects faced two investment alternatives, comprising two similar structured products. The sole distinction between the alternatives is that returns on the first are contingent on an outcome that has occurred in the recent past, while those of the second are contingent on an outcome not recently experienced. All other conditions are equal. 
The existence of a hindsight bias is supported if a majority of investors prefer the investment whose return depends on an outcome that has recently occurred.

\section{$\underline{\text { Results }}$}

Investor selections are summarized in Table 6 . The left column represents the percentage of investors who preferred the "hindsighted" structured product over the other.

Table 6

\begin{tabular}{|c|c|}
\hline $\begin{array}{c}\text { Outcome that has } \\
\text { recently occurred }\end{array}$ & $\begin{array}{c}\text { Outcome that did } \\
\text { not occur }\end{array}$ \\
\hline $77.24 \%$ & $22.76 \%$ \\
& \\
\hline
\end{tabular}

Table 6 reveals that $77.24 \%$ of the subjects preferred the hindsighted structured. The results yielded a significant chi square statistic $\chi^{2}(1)=79.53, p<0.001$. Consequently, the hindsight bias does apparently come into play in investor decision-making. 


\section{Summary}

Structured products are synthetic investment instruments specially designed to meet specific needs that cannot be met by acquiring standard financial instruments available in the markets. Structured products can be used as an alternative to direct investments in financial assets, as a means to mitigate risk exposure of a portfolio, or as a way of exploiting market trends. Interest in these investments grown in recent years and a significant portion of investor capital has been invested in structured products.

We outlined several key features embedded in various structured products and associated each with specific behavioral bias identified in the literature of decision theory. These include: loss aversion, the disposition effect, herd behavior, the ostrich effect, and hindsight bias.

We performed an experiment to test the possible impact of each behavioral bias on decisions pertaining to investments in structured products. Our findings reveal that, to varying degrees, the examined behavioral biases affect investor decisions in a manner favoring the investment in structured products.

In demonstrating the impact of these behavioral biases on investors, our results can support the institution of specific regulation for structured products to improve investor protection. Such regulation would compel issuers to reveal the effective fees they charge investors. In disclosing the effective fees the investors will be able to compare between investment alternatives and will be able to decide if they are willing to pay this amount for the recognized behavioral bias. 
$\underline{\text { Appendix 1; Association between Structured Product Features and Behavioral Biases }}$

\begin{tabular}{|c|c|c|c|}
\hline Feature & Behavioral Bias & $\underline{\text { References }}$ & Examples \\
\hline Principal Protection & Loss Aversion & $\begin{array}{l}\text { Kahneman D. and A. Tversky., } \\
\text { "Prospect Theory: An Analysis of } \\
\text { Decision Under Risk," Econometrica, } \\
47 \text { (1979), 263-291. } \\
\text { Benartzi, S., \& R.H. Thaler, "Myopic } \\
\text { Loss Aversion and the Equity Premium } \\
\text { Puzzle," Quarterly Journal of } \\
\text { Economics, } 110 \text { (1995), 73-92. }\end{array}$ & $\begin{array}{l}\text { Principal- } \\
\text { protected market- } \\
\text { linked } \\
\text { instruments }\end{array}$ \\
\hline $\begin{array}{l}\text { Mandatory } \\
\text { Conversion to a } \\
\text { "loser" asset }\end{array}$ & $\begin{array}{l}\text { The Disposition } \\
\text { Effect }\end{array}$ & $\begin{array}{l}\text { Shefrin H. and M. Statman, "The } \\
\text { Disposition to Sell Winners Too Early } \\
\text { and Ride Losers Too Long: Theory and } \\
\text { Evidence", Journal of Finance, } 40 \\
\text { (1985), 777-790. }\end{array}$ & $\begin{array}{l}\text { Mandatory } \\
\text { convertible bonds }\end{array}$ \\
\hline $\begin{array}{l}\text { Investment in } \\
\text { Emerging Markets } \\
\text { and Exotic } \\
\text { Financial Products }\end{array}$ & Herd Behavior & $\begin{array}{l}\text { Leibenstein, H., "Bandwagon, Snob, } \\
\text { and Veblen Effects in the Theory of } \\
\text { Consumers' Demand," Quarterly } \\
\text { Journal of Economics, } 64 \text { (1950), 183- } \\
207 . \\
\text { Bikhchandani, S., D. Hirschleifer, and I. } \\
\text { Welch. "A Theory of Fad, Fashion, } \\
\text { Custom and Cultural Change as } \\
\text { Informational Cascades," Journal of } \\
\text { Political Economy, } 100 \text { (1992), 992- } \\
\text { 1026. }\end{array}$ & $\begin{array}{l}\text { Market-linked } \\
\text { structured notes } \\
\text { on emerging } \\
\text { market indices }\end{array}$ \\
\hline Illiquidity & $\begin{array}{l}\text { The Ostrich } \\
\text { Effect }\end{array}$ & $\begin{array}{l}\text { Galai D. and O. Sade, "The 'Ostrich } \\
\text { Effect' and the Relationship Between } \\
\text { the Liquidity and the Yields of Financial } \\
\text { Assets," Journal of Business, 79(5), } \\
\text { 2006, 2741-2759. }\end{array}$ & $\begin{array}{l}\text { Non-negotiable } \\
\text { structured } \\
\text { products }\end{array}$ \\
\hline $\begin{array}{l}\text { Reliance on } \\
\text { Outcome that has } \\
\text { Occurred }\end{array}$ & Hindsight & $\begin{array}{l}\text { Fischhoff B., "Hindsight } \neq \text { Foresight: } \\
\text { the Effect of Outcome Knowledge on } \\
\text { Judgment under Uncertainty," Journal } \\
\text { of Experimental Psychology, 1, 1975, } \\
288-299 . \\
\text { Fischhoff, B., \& R. Beyth,. "I Knew It } \\
\text { Would Happen" - Remembered } \\
\text { Probabilities of Once-future Things. } \\
\text { Organizational Behavior and Human } \\
\text { Performance, 13, 1975, 1-16. }\end{array}$ & $\begin{array}{l}\text { Most structured } \\
\text { products }\end{array}$ \\
\hline
\end{tabular}




\section{Appendix 2- The Experiment}

\section{Instructions:}

- A given sum of money is at your disposal for investment in the best possible investment.

- You are presented with a number of investment decisions. You must choose only one of the mutually-exclusive investment alternatives for each decision.

- The investment decisions are not related and each should be considered separately.

- The funds available to you are equal for each decision, and hence for each mutuallyexclusive investment alternative.

\section{$\underline{\text { Investment decision } 1}$}

a. Investment of the money at your disposal in a one-year deposit that is contingent on the exchange rate between the Israeli Shekel (NIS) and the Swiss franc. For every NIS 60 invested in the deposit, at the end of the year you will receive either NIS 130 if the NIS/ Swiss franc increases, or NIS 60 if the NIS/Swiss franc decreases.

b. Investment of the money in a one-year deposit. For every NIS 60 invested you will receive NIS 90 at the end of the year.

The amount to be remitted at the end of the year includes the principal and no additional amounts shall be received.

\section{$\underline{\text { Investment decision } 2}$}

a. Investment of the money at your disposal in a one-year deposit with a guaranteed interest rate of $9 \%$ at the end of the year. The outcome of the principal is contingent on the rate of return on Teva shares during the year. If the price of Teva shares fall by $15 \%$ or more in relation to the quoted price of the shares on the date of investment during this period, the principal of the deposit will be converted into Teva shares, based on their value at the beginning of the year. The conversion will take place at the end of the year and you will receive an additional $9 \%$ interest. If this condition is not fulfilled, the principal will be returned in full with an additional $9 \%$ interest.

b. Investment of the money in a one-year deposit with a guaranteed interest rate of $9 \%$ at the end of the year. The outcome of the deposit principal is contingent on the quoted price of Teva shares. If the price of Teva falls over the year by $15 \%$ or more in relation to the quoted price of the shares on the date of investment, $85 \%$ or less (accordingly) of the initial amount invested will be paid in cash with an additional $9 \%$ interest. If this condition is not met, the principal will be returned in full with an additional $9 \%$ interest.

\section{Investment decision 3}

a. Investment of the money at your disposal in a one-year deposit that is linked to the increase in the Indian share price index. If the share index increases, the principal shall appreciate in accordance with the relative increase of the Indian share price index. If the index decreases or remains unchanged, the principal will be returned at the end of the year with no additional payments.

b. Investment of the money at your disposal in a one-year deposit that is linked to the increase in the Italian Stock Exchange share price index. If the share price index increases, the 
principal will appreciate in accordance with the relative increase of the index. If the share price index decreases or remains unchanged, the principal will be returned at the end of the year and no additional payments.

The rates of return for the two stock indexes in the previous year were identical.

\section{$\underline{\text { Investment decision } 4}$}

a. Investment of the money that is at your disposal in a one-year deposit that is dependent on the exchange rate of the Swiss franc. For every NIS 80 invested in the deposit, at the end of the year you will receive either NIS 130, if the NIS/Swiss france exchange rate, or NIS 60 if the exchange rate decreases.

b. Investment of the money that is at your disposal in a one-year deposit. For every NIS 80 invested you will receive NIS 90 at the end of the year.

The amount remitted at the end of the year includes the principal and no additional sums will be paid.

\section{$\underline{\text { Investment decision } 5}$}

a. Investment of the sum at your disposal in a one-year deposit that is linked to the performance of a fund that invests in technology start-ups. If the value of the fund increases, the principal invested will appreciate in accordance with the relative increase of the value of the fund. If the value of the fund decreases or remains unchanged, the principal will be returned at the end of the year and no additional payments will be made.

b. Investment of the money that is at your disposal in a one-year deposit that is linked to the performance of a "cleantech" fund, which invests in companies that are engaged in environmental technologies. If the value of the fund increases, the principal invested will appreciate by the relative increase in the value of the fund. If the value of the fund decreases or remains unchanged, the principal will be returned at the end of the year and no additional sums will be received.

In the previous year both funds yielded the same return.

\section{$\underline{\text { Investment decision } 6}$}

a. Investment of the money at your disposal in a one-year deposit that grants NIS 110 at the end of the year for every NIS 100 invested, with no option for early withdrawal.

b. Investment of the money in a one-year deposit that grants NIS 110 at the end of the year for every NIS 100 invested. The deposit may be withdrawn during the year at the market value on the date of withdrawal, which may be less than NIS 100.

\section{$\underline{\text { Investment decision } 7}$}

a. Investment of the money at your disposal in a one-year deposit that grants interest at the rate of $10 \%$, provided that the quoted price of a given share increases by at least $10 \%$ during the year. In the previous year the quoted share price increased by $10 \%$. If this condition is not fulfilled, the money invested is returned in full and no additional amounts shall be received. 
b. Investment a one-year deposit that grants interest at the rate of $10 \%$ provided that the quoted price of a given share increases by at least $10 \%$ during the year. In the preceding year the quoted share price did not increase by $10 \%$. If this condition is not fulfilled, the money invested is returned in full and no additional sums will be paid.

To what extent do you identify with each of the following statements?

Rank on a scale of $1-10$, with $1=$ not at all and $10=$ very much

Protection of the environment is important

Supporting entrepreneurial start-ups is important

Investment in markets of developing countries is important 


\section{$\underline{\text { References }}$}

Barberis N., A. Shleifer A. and R. Vishny., "A Model of Investor Sentiment”, Journal of Financial Economics, 49 (1998), 307-343.

Benartzi, S., and R.H. Thaler, "Myopic Loss Aversion and the Equity Premium Puzzle," Quarterly Journal of Economics, 110 (1995), 73-92.

Bethel J. and A.Ferrel , Policy Issues Raised by Structured Products, Discussion Paper No. 560., John M. Olin Center for Law, Economics and Business, Harvard Law School, (2007).

Bikhchandani, S., D. Hirschleifer, and I. Welch, "A Theory of Fad, Fashion, Custom and Cultural Change as Informational Cascades," Journal of Political Economy, 100 (1992), 992-1026.

Daniel, K., D. Hirshleifer and A. Subrahmanyam, "Investor Psychology and Security Market Over- and Under-reactions,” Journal of Finance, 53 (1998), 1839-1885.

Fischhoff B., Hindsight $\neq$ Foresight: "The Effect of Outcome Knowledge on Judgment under Uncertainty”, 1, Journal of Experimental Psychology (1975), 288-299.

Fischhoff, B. and R. Beyth. "I Knew It Would Happen"- Remembered Probabilities of Once-future Things," Organizational Behavior and Human Performance, 13 (1975), 116.

Galai D. and O. Sade, "The 'Ostrich Effect' and the Relationship Between the Liquidity and the Yields of Financial Assets," Journal of Business, 79(5) (2006), 2741-2759.

Grünbichler A. and H. Wohlwend, "The Valuation of Structured Products: Empirical Findings for the Swiss Market," Financial Markets and Portfolio Management 19(4) (2005), 361-380.

Heath C., S. Huddart and M. Lang, "Psychological Factors and Stock Option Exercise," The Quarterly Journal of Economics, 114(2) (1998), 601-627.

Kahneman D. and A. Tversky A., "On the Psychology of Prediction," Psychological Review, 80 (1973), 237-251.

Kahneman D. and A. Tversky, "Prospect Theory: An Analysis of Decision under Risk," Econometrica, 46 (1979), 171-185.

Katz, M. L., and C. Shapiro, "Network Externalities, Competition, and Compatibility," The American Economic Review, 75 (June 1985), 424-440.

Leibenstein, H., "Bandwagon, Snob, and Veblen Effects in the Theory of Consumers' Demand," Quarterly Journal of Economics 64 (1950), 183-207. 
Levy, H. "Risk and Return: An Experimental Analysis," International Economic Review 38 (1) (1997), 119-49.

Levy, H. and M. Levy, "Experimental Test of the Prospect Theory Value Function," Organizational Behavior and Human Decision Processes, 89(2), (2002), 1058-1084.

McCann C. and L. Dengpan., Are Structured Products Suitable for Retail Investors?, working paper, electronic copy available at:

investor.financialcounsel.com/Articles/Investment/ARTINV0000296-

StructuredProducts.pdf

Shefrin H. and M. Statman., "The Disposition to Sell Winners Too Early and Ride Losers Too Long: Theory and Evidence," Journal of Finance, 40 (1985), 777-790.

Stoimenov P. A. and Wilkens S., "Are Structured Products 'Fairly' Priced? An Analysis of the German Market for Equity-linked Instruments," Journal of Banking \& Finance 29(12), (2005), 2971-2993.

Tversky, A. and D. Kahneman,'Loss Aversion and Riskless Choice: A Reference Dependent Model," Quarterly Journal of Economics, 106 (1991), 1039-1061

Vanini P. and B. Döbeli., Revealed and Stated Investment Decisions Concerning Structured Products, working paper, electronic copy available at: $\mathrm{http}: / /$ ssrn.com/abstract $=991868$

Wilkens S., C. Erner and K. Röder, "The Pricing of Structured Products in Germany", The Journal of Derivatives 11, (2003), 55-69. 